Journal of Qualitative Criminal Justice \& Criminology

\title{
Book Review | Courting \\ Kids: Inside an \\ Experimental Youth Court
}

\author{
Avi Brisman ${ }^{1}$ \\ ${ }^{1}$ Eastern Kentucky University
}

Published on: Oct 01, 2013

Updated on: Jul 17, 2020

DOI: $10.21428 / 88 d e 04 a 1.3 f 554 b 6 d$

License: Creative Commons Attribution 4.0 International License (CC-BY 4.0). 
Carla J. Barrett. Courting Kids: Inside an Experimental Youth Court. New York University Press, 2013; 212 pp.; ISBN: 9780814709450.

In the late 1980s and early 1990s, the United States witnessed a small increase in youth violence, particularly a rise in gun violence among young African-American urban males. This spike in gun violence was localized and primarily linked to turmoil surrounding the introduction of crack cocaine into many cities around the country-metropolitan areas that were already experiencing crushing economic pressures, unemployment, and decaying neighborhoods. There was no evidence of an overall nationwide surge in "youth crime" or "juvenile crime" - terms that became conflated with serious "youth violence," which, in turn, became code for "dangerous young black or brown men." Despite this reality, a racialized moral panic took hold, focusing on an emerging generation of young "superpredators."

In response to the perceived threat of hyperviolence perpetrated by poor, young, urban AfricanAmerican and Hispanic males, states changed their laws, allowing more youths to be tried as adults in criminal courts (often for nonviolent crimes, such as drug and property offenses), thereby denying these young people the rehabilitation-centered treatments typically provided within the setting of juvenile courts. This punitive "transfer" or "waiver" legislation-so-called because it historically involved the transfer or waiver of young defendants from the jurisdiction of a juvenile court system to that of a criminal court- "flourished in a time of misconception about the amount and percentage of crime attributable to young people," Barrett explains, "compounded by mounting fear of the urban nonwhite male teenager, all set within a larger trend of retributive justice policy and resulting massincarceration movement" (p. 11). "Across the 1990s," she continues, "changes to transfer laws substantially rewrote legal and social policy in regard to youth, which in turn has altered the legal, social, and criminologi cal discourse on appropriate or inappropriate responses to youth violence, juvenile delinquency, the degree of culpability among the young, and their perceived amenability to treatment" (pp. 11-12). These policy changes that were introduced in the 1990s and that have served to routinize the criminal prosecution of youth are still prevalent across the country, and have created a unique category of defendant in criminal courtrooms - what Barrett, an assistant professor in the Department of Sociology at John Jay College of Criminal Justice, City University of New York, refers to as the "adult-juvenile" - an individual "under the age of 18 caught in a legal limbo: legally labeled within the justice system as an adult for the purposes of criminal prosecution, yet still defined as a minor in all other legal and social settings" (p. 12). This criminal prosecution of adolescents has produced a range of challenges for judges, defense attorneys, prosecutors, and other criminal-court actors, who must "filter" transfer laws-alter or adjust their case processing to reconcile the inherent contradictions of prosecuting youths as if they were adults. Courting Kids: Inside an Experimental Youth 
Court is Barrett's ethnographic account of how the Manhattan Youth Part, a courtroom in New York City set aside for criminal cases involving youths who are required by law to be prosecuted as adults, sought to filter New York's transfer laws. It is a moving tale of how court actors, led by Judge Michael Corriero (who presided over the Manhattan Youth Part from its creation in 1992 to his retirement in 2007), struggled to "hold young defendants, nearly all of them black and/or Hispanic males between the ages of 14 and 18, accountable for their alleged crimes while acknowledging their adolescence and attempting to divert them away from the full force of the adult sentences they were facing" (p. 2). But it is more than that. Because, as Barrett asserts, "[o]ne cannot, should not, research, theorize, or write about judicial processes in U.S. courts without researching, theorizing, and writing about race" (pp. 1718), Courting Kids is also an indictment of racial disparities in the system of criminal (in)justice in the United States.

Courting Kids: Inside an Experimental Youth Court is divided into six chapters, along with an introduction and a conclusion. In the introduction, "An Experiment in Youth Justice," Barrett provides an overview of and background on the Manhattan Youth Part's creative efforts to provide legal alternatives within the statutory constraints of retributive law, for AfricanAmerican and Hispanic youths from poor urban communities facing felony charges and possible incarceration. Barrett clearly and succinctly describes juvenile justice prior to the 1990s, the superpredator moral panic that led to the criminalization of youth and "transfer law boom" in 1990s, the impact of transfer laws on case processing, and her methods for conducting research on the Manhattan Youth Part.

Chapter One, "Calendar Days in the Youth Part," builds on the introduction to further explain the history of New York's criminal prosecution of youth and the genesis of the Manhattan Youth Part, and provides a description of a typical "calendar day" in the courtroom of the Manhattan Youth Part. Barrett's exquisite detail of the sounds, space, and rhythms of the courtroom transports us to the floor of the building in downtown Manhattan, where the court is located, enabling us to more fully appreciate the mundanity and drama of case processing, while heightening our awareness of the racial and gender dynamics of the court.

Chapter Two, "Creating the 'Juvenile Offender,"' offers a history of New York state law related to youthful offending, beginning with the 1978 Juvenile Offender Law-the first in the country to allow criminal prosecution of youth under age 16 without juvenile court oversight - which set an early precedent for the routine prosecution of youths as adults. Barrett concludes Chapter Two with an examination of data on indictments in New York City from the mid-1980s to the mid-2000s, highlighting the demographic trends among youths prosecuted as adults in the city.

With this historical and demographic backdrop, Barrett demonstrates, in Chapters Three, Four, and Five, the many challenges that she witnessed in the day-to-day case processing of young defendants and the innovative strategies that the court employed in response to them. Chapter Three, 
"Rehabilitation, Youth Part Style," shows how the court used intentional delay and calculated judicial discretion in concert with alternative-to-incarceration programs to enable a young defendant to "earn back his juvenile status" - to receive a sentence as a "Youthful Offender," which, provided the youth stayed out of trouble and did not violate the terms of his probation over a set period of time, would enable his criminal records to be sealed, thereby removing the stigma of "felon" and the requirement to declare his felonious transgressions on job applications and elsewhere.

Chapter Four, "Individualized Justice in a Criminal Court," is the most ethnographically rich part of the book. Here, Barrett reveals her talents as a qualitative researcher, using courtroom narratives to demonstrate how the culture and day-to-day practices of the Manhattan Youth Part reconceptualized the original parens patriae philosophy of juvenile courts with their emphasis on individualized justice, child-saving strategies, and rehabilitative goals. We feel that we get to know the young people passing through the court - no small feat given that Barrett did not interview any of the youth defendants. She concludes the chapter with a comparison of her findings with those of Aaron Kupchik, whose Judging Juveniles: Prosecuting Adolescents in Adult and Juvenile Courts, in tandem with Courting Kids, furthers our understanding of how criminal courts grapple with the realities of trying youths as adults.

Chapter Five, "Managing Contradictions," focuses on the contradictions between the legal and social status of the "kids" - the common descriptor Barrett intentionally employs to humanize and reflect the reality of courtinvolved youth. Here, Barrett highlights the fundamental irrationality of the adult prosecution of adolescents, providing a springboard for her critical discussion, in Chapter Six, "Judging the Court, Judging Transfer," of the criminal prosecution of youth (in general), the Manhattan Youth Part practices (in particular), and what the future might hold for legal responses to adolescent transgression and the practice of prosecuting youths as adults.

Barrett concludes, in "Kids Will Be Kids," with a discussion of how the experiment in justice undertaken by the Manhattan Youth Part provides a model for responding to serious adolescent lawbreakers - a model that holds kids accountable for their actions, allows for a consideration of the reality of their youthful (and frequently troubled) lives, and brings a measure of empathy and humanity to the practice of rehabilitative justice in an era of retribution.

In sum, Courting Kids: Inside an Experimental Youth Court is an insightful account of the proper (and improper) legal responses to youth offenders, about the (un)tenability of prosecuting kids as adults, and about the ongoing criminalization of youth. While Barrett could have written a rallying cry for reform - and while anyone who has kids, knows kids, or was once a kid will at times be saddened and at others enraged by what is revealed in the book - her restraint, combined with careful analysis and cogent critique, renders Courting Kids an invaluable tool in sorting out how to balance the idea that some kids should be punished harshly for committing serious crimes with the notion that adolescents 
are different from adults and therefore worthy of sentencing alternatives and attempts at rehabilitation. 